SHORT COMMUNICATION

\title{
First record of Neoechinorhynchus buttnerae (Eoacantocephala, Neochinorhynchidae) on Colossoma macropomum (Characidae) in a fish farm in Roraima, Brazil
}

\author{
Jeffson Nobre PEREIRA, Germán Augusto Murrieta MOREY* \\ Instituto Nacional de Pesquisas da Amazônia - INPA, Programa de Pós-graduação em Biología de Água Doce e Pesca Interior - BADPI, Av. André Araújo 2936, \\ Petrópolis, CEP 69067-375 Manaus, Amazonas, Brazil \\ * Corresponding author: germantiss@hotmail.com; germantiss1106@gmail.com
}

\begin{abstract}
Severe infections by the acanthocephalan Neoechinorhynchus buttnerae were reported in Colossoma macropomum in fish farms in northern Brazil. The occurrence of the parasite is recorded for the first time in the state of Roraima, Brazil, along with its parasite indexes. Fifty C. macropomum from a fish farm were analyzed. We collected a total of 13474 individual parasites. Neoechinorhynchus buttnerae had a prevalence of $100 \%$, and mean intensity and mean abundance of 269.48. Significant positive correlations were observed between fish standard length, weight and relative condition factor and the number of parasites. Our results showed evident loss of body mass in the parasitized fish. Fish farmers in Roraima should be advised to manage the infection of C. macropomum by N. buttnerae, as massive infections of this parasite can deteriorate the health of the fish.

KEYWORDS: Acanthocephala, intestine, parasites, parasitic indexes, tambaqui

\section{Primeiro registro de Neoechinorhynchus buttnerae (Eoacantocephala, Neochinorhynchidae) em Colossoma macropomum (Characidae) em uma fazenda de peixes em Roraima, Brasil}

\section{RESUMO}

Infecçóes severas pelo acantocéfalo Neoechinorhynchus buttnerae foram relatados em Colossoma macropomum em fazendas no norte do Brasil. O objetivo do presente estudo foi avaliar o primeiro registro de ocorrência deste parasita no estado de Roraima, Brasil, relatando seus índices parasitários. Cinquenta C. macropomum de uma fazenda foram analisados. Coletamos um total de 13474 parasitas. Neoechinorhynchus buttnerae mostrou uma prevalência de $100 \%$, com uma intensidade média e abundância média de 269,48. O comprimento padrão, peso e fator de condição relativo dos peixes foram correlacionados positiva e significativamente com o número de parasitas. Nossos resultados mostraram perda evidente de massa corporal nos peixes. Nosso registro da presença de $N$. buttnerae infectando C. macropomum no estado de Roraima é um alerta aos piscicultores, pois infecçôes massivas podem deteriorar a saúde dos peixes.

PALAVRAS-CHAVE: Acanthocephala, índices parasitários, intestino, parasitas, tambaqui 
The tambaqui, Colossoma macropomum (Cuvier, 1818) is the principal native Amazonian fish species reared in Brazil (IBGE 2014), and has great acceptance by consumers, and high commercial value (Melo et al. 2001). Its success in aquaculture is due to characteristics such as rapid growth, omnivorous feeding behavior, and its capacity to support a great variation in physical and chemical characteristics of the water (Melo et al. 2001; Gomes et al. 2010).

Colossoma macropomum is mainly produced in the Amazon region in semi-intensive and intensive systems (Izet $e t$ al. 2013). In the north of Brazil, some cases of acanthocephalan dissemination have been reported (Noga 2010). Recently, severe infections by the acanthocephalan Neoechinorhynchus buttnerae (Golvan, 1956) have been described in Rondônia, causing economic losses in fish farms (Chagas et al. 2015; Oliveira et al. 2015).

Fish growth can be affected by $N$. buttnerae infection, since this parasite uses its proboscis to attach to the intestine tissue, causing health and pathological alterations (Melo et al. 2014). Due to the importance of $N$. buttnerae in fish farming, the present study reports its occurrence in a fish farm in Roraima, in order to observe pathological alterations and calculate the parasite indexes in heavily infected C. macropomum.

Fifty C. macropomum individuals with mean $23.6 \pm 4.9 \mathrm{~cm}$ standard length and mean $360 \pm 59.8 \mathrm{~g}$ weight were collected from a dam in a fish farm located in the state of Roraima, Brazil, $\left(02^{\circ} 58^{\prime} 48^{\prime \prime} \mathrm{N} / 61^{\circ} 17^{\prime} 31^{\prime \prime} \mathrm{W}\right)$ in June 2017. Fish were collected with the help of local farm hands. The collected fish were irreversibly anesthetized with Eugenol diluted in water $\left(80 \mathrm{mg} \mathrm{L}^{-1}\right)$ and killed by cerebral concussion. The fishes were then measured and weighed, and the intestinal tract was removed and opened lengthwise to quantify the parasites. The acanthocephalans were removed from the intestine and fixed in AFA (alcohol formaldehyde and acetic acid) solution under cover slip pressure. Specimens were stained with Langeron's alcoholic carmine, cleared in Eugenol and mounted in Canada balsam as permanent slides (Amato et al. 1991). Voucher specimens were deposited in the non-insecta invertebrate collection of the Instituto Nacional de Pesquisas da Amazônia (INPA).

The following ecological parameters of the parasitological infection were determined according to Bush et al. (1997): prevalence (number of infected fish / total number of fish examined $\times 100$ ), intensity (the number of individuals of a particular parasite species in a single infected host, expressed as a numerical range), mean intensity (total number of parasites / number of infected hosts), mean abundance (total number of parasites /number of infected and non-infected hosts). According to Le Cren (1951), the condition factor is a quantitative indicator of fish fitness, reflecting recent feeding condition. The relative condition factor of fish, being a measure or a quantitative indicator of welfare, can serve as a tool to study the relationship between health and natural parasitism (Lizama 2003).
The relative condition factor was calculated using the values of standard length $(\mathrm{L})$ and total weight $(\mathrm{Wt})$ of each host adjusted to the relationship curve $\mathrm{Wt} / \mathrm{Ls}(\mathrm{Wt}=\mathrm{a} . \mathrm{Ltb})$ and was used to estimate values of the regression coefficients "a" and "b". The "a" and "b" values were used to estimate the expected values for weight $(\mathrm{We})$ using the equation: $\mathrm{We}=\mathrm{a} . \mathrm{Ltb}$. The relative condition factor $(\mathrm{Kn})$ corresponds to the ratio between observed weight and expected weight for a given length $(\mathrm{Kn}=$ Wt/ We) (Le Cren 1951). The Shapiro-Wilk W statistic was used to test for normality of distributions. Spearman's correlation test was used to evaluate the correlation between the total number of parasites and the fish standard length, weight and relative condition factor of the hosts.

Neoechinorhynchus buttnerae (Figure 1) was present in all sampled fish (prevalence of $100 \%$ ), with a total number of 13474 individuals, and intensity varying from 188 to 388 parasites per fish. The mean intensity and mean abundance were 269.5. The parasites were present along the entire intestine. The infected fish were thin and with evident loss of body mass (Figure 2). The relative condition factor (Kn) of the fish was $0.99 \pm 0.10$. There were significant positive correlations between the number of $N$. buttnerae and the standard length, weight and relative condition factor of the hosts $(r=0.4915, p=0.0003 ; r=0.6171, p=0.0001 ; r=$ $0.4493, p=0.0011$, respectively).

The first occurrence in the world of $N$. buttnerae was described by Golvan (1956) from infected C. macropomum captured near Manaus, in the state of Amazonas, Brazil (Thatcher 1991). Subsequent records were from $C$.

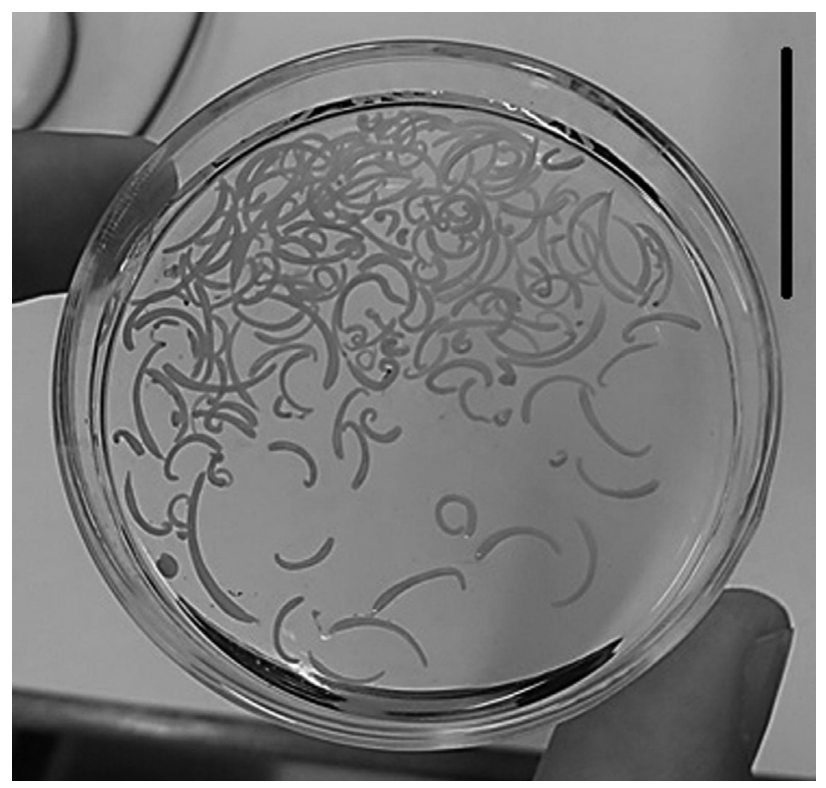

Figure 1. Neoechinorhynchus buttnerae (Golvan, 1956) collected from Colossoma macropomum (Cuvier, 1818) from a fish farm in the state of Roraima, Brazil. Scale bar $=40 \mathrm{~mm}$. 


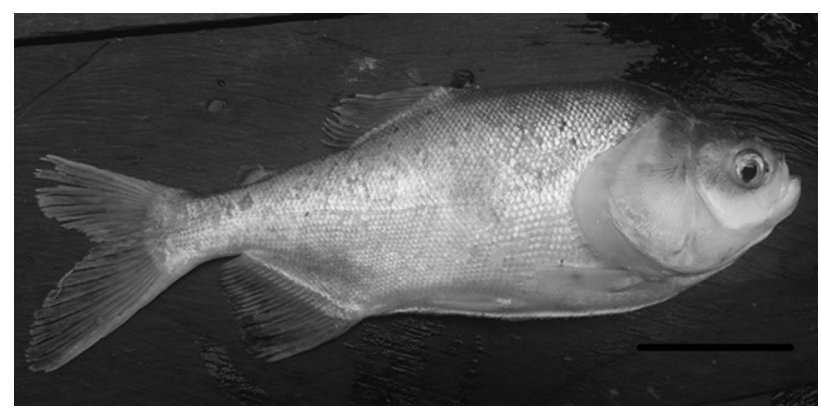

Figure 2. Colossoma macropomum (Cuvier, 1818) infected by Neoechinorhynchus buttnerae (Golvan, 1956) showing signs of loss of body mass. Bar scale $=50 \mathrm{~mm}$.

macropomum captured near Leticia, Colombia (Schmidt and Huggins 1973), in Tefé and Coari, in the central Brazilian Amazon, and in Santarém, in the state of Pará (Fischer 1998). The first occurrence of this parasite in a fish farm was from C. macropomum in Manaus (Malta et al. (2001). Recently, high infestation rates have also been reported in the state of Rondônia and other localities in Amazonas (Jerônimo et al. 2016), and in different fish farms in Manaus (Silva-Gomes et al. 2017). In this study we registered the first occurrence of $N$. buttnerae in the state of Roraima, Brazil. In this way, the geographical distribution of this parasite is expanded to a new state in northern Brazil.

The parasitism by $N$. buttnerae caused great impact on the growth of the fish and had a large impact on the production (Silva-Gomes et al. 2017). The fish can survive the infection, but their development is hampered, because the parasite competes with the host for the nutrients consumed by the fish, affecting its development (Silva-Gomes et al. 2017). The high parasitic indexes registered and the evident signs of malnutrition in all C. macropomum analyzed in this study reinforce this hypothesis.

The increase of parasites in an infracommunity occurs by simple accumulation, as a result of the increase of the size of the fish. In this way, larger fish are expected to have a greater number of parasites, due to the greater availability of space (Dogiel 1970). In the present study larger C. macropomum were more parasitized by $N$. buttnerae, accumulating more specimens than small ones.

According to Bauer (1970), the pathogenic activity of parasites necessarily affects host condition in a negative way, but largest individuals with the highest Kn tolerate higher levels of parasitism (Cone 1995). In this study the Kn of the infected fish was considered normal, and the positive correlation between the weight and $\mathrm{Kn}$ of infected $C$. macropomum and the number of $N$. buttnerae can be explained by the high number of parasites in the intestines, which may influence the weight of the fish, overestimating the real weight values. This phenomenon needs to be further investigated in studies comparing the Kn of infected and non-infected fish.
Considering the presence of $N$. buttnerae in the state of Roraima, and the intensity of the infection recorded in $C$. macropomum, it is recommended that tambaqui fish farmers in the state carefully monitor their breeding stocks and take prophylactic measures to avoid massive infections by this parasite that can deteriorate the health of the fish, and cause considerable economic losses.

\section{ACKNOWLEDGEMENTS}

The authors thank the support of Laboratório de Parasitología de Peixes (LPP) of the Instituto Nacional de Pesquisas da Amazônia - INPA. GAMM received a doctoral scholarship from Coordenação de Aperfeiçoamento de Pessoal de Nível Superior (CAPES).

\section{REFERENCES}

Amato, J. F. R.; Boeger, W. A.; Amato, S. B. 1991. Protocolos para laboratório coleta e processamento de parasitas do pescado. Imprensa Universitária, Universidade Federal do Rio de Janeiro, Rio de Janeiro, Brasil, 81p.

Bauer, O. N. 1970. Parasites and Diseases of USSR coregonids. In: Lindsey, C.C.; Woods, C.S. (Eds.). Biology of coregonid fishes. University of Manitoba Press, Winnipeg, p.267-278.

Bush, A.O., Lafferty, K.D., Lotz, J.M., Shostak, A.W. 1997. Parasitology meets ecology on its own terms: Margolis et al. revisited. The Journal of Parasitology, 83: 575-583.

Chagas, E.C., Maciel, P.O., Aquino-Pereira, S.L. 2015. Infecçōes por acantocéfalos: um problema para a produção de peixes. In: Tavares-Dias, M., Mariano, W.S. (Orgs.) Aquicultura no Brasil: novas perspectivas. [Vol. 1]. Aspectos Biológicos, Fisiológicos e Sanitários de Organismos Aquáticos. Chapter 16. São Carlos: Pedro \& João Editores, São Carlos, p.305-328.

Cone, D.K. 1995. Monogenea (Phylum Platyhelminthes). In: Woo, P.T.K. (Eds.). Fish diseases and disorders. Protozoan and Metazoan Infections. CABI, Wallongford. p.289-328

Dogiel, V.A. 1970. Ecology of the parasites of freshwater fishes. In: Dogiel, V. A., Petrushevski, G. K., Polyansky, Y. I. (Eds.). Parasitology of fishes. Olivier \& Boyd, London. p.1-47.

Fischer, C. 1998. A fauna de parasitas do tambaqui Colossoma macropomum (Cuvier, 1818) (Characiformes: Characidae) do medio rio Solimoes (A M) e baixo rio Amazonas(PA) e seu potencial como indicadores biologicos. Master's dissertation. Instituto Nacional de Pesquisas da Amazonia, Fundação Universidade do Amazonas. Manaus, Brasil. 63p.

Gomes, L.C., Simóes L.N., Araujo-lima, C.A. 2010. Tambaqui (Colossoma macropomum). In: Baldisserotto, B., Gomes, L.C. (Eds.). Espécies Nativas para piscicultura no Brasil - Santa Maria: Editora UFSM, P.175-204.

Instituto Brasileiro de Geografia e Estatística [IBGE], 2014. Produção da Pecuária Municipal 2013. Vol. 41. IBGE, Rio de Janeiro. 108p. (ftp://ftp.ibge.gov.br/Producao_Pecuaria/ Producao_da_Pecuaria_Municipal/2013/pp m2013.pdf). Accessed on 18 July 2017. 
Izel, A.C.U., Crescêncio, R., O`Sullivan, F.F.., Chagas, E.C., Boijink, C.L., Silva, J.I. 2013. Produção intensiva de tambaqui em tanques escavados com aeração. Embrapa Amazônia Ocidental (Circular Técnica 39), Manaus. 4p.

Jerônimo, G.T., de Pádua, S.B., de Andrade Belo, M.A., Chagas, E.C., Taboga, S.R., Maciel, P.O., \& Martins, M.L. 2017. Neoechinorhynchus buttnerae (Acanthocephala) infection in farmed Colossoma macropomum: a pathological approach. Aquaculture, 469: 124-127.

Le Cren, E.D. 1951. The length-weight relationship and seasonal cycle in gonad weight and condition in the perch Perca fluviatilis. Journal of Animal Ecology, 20: 201-219.

Malta, J.C.O., Gomes, A.L.S., Andrade, S.M.S., Varella, A.M.B. 2001. Infestaçóes maciças por acantocéfalos, Neoechinorhynchus buttnerae Golvan, 1956, (Eoacanthocephala: Neoechinorhynchidae) em tambaquis jovens, Colossoma macropomum (Cuvier, 1818) cultivados na Amazônia central. Acta Amazonica 31: 133-143.

Melo, L.A.S., Izel, A.C.U., Rodrigues, F.M. 2001. Criação de tambaqui (Colossoma macropomum) em viveiros de argila/ barragens no Estado do Amazonas. Embrapa Amazonia Ocidental, Manaus, $25 \mathrm{p}$.

Melo, F.T.D.V., Rodrigues, R.A.R., Giese, E.G., Gardner, S.L., Santos, J.N.D. 2014. Histopathologic aspects in Plagioscion squamosissimus (HECKEL, 1940) induced by Neoechinorhynchus veropesoi, metacestodes and anisakidae juveniles. Brazilian Journal Veterinarian Parasitology, 23: 224-230.
Oliveira, S.R.K.S., Bezerra, M.V.P., Belo, M.A.A. 2015. Estudo da endofauna parasitária do tambaqui Colossoma macropomum, em pisciculturas do Vale do Jamari, Estado de Rondônia. Enciclopédia Biosfera 11: 1026-1041.

Silva-Gomes, A. L., Gomes Coelho-Filho, J., Viana-Silva, W., BragaOliveira, M. I., Bernardino, G., Costa, J. I. 2017. The impact of Neoechinorhynchus buttnerae (Golvan, 1956) (Eoacanthocephala: Neochinorhynchidae) outbreaks on productive and economic performance of the tambaqui Colossoma macropomum (Cuvier, 1818), reared in ponds. Latin American Journal of Aquatic Research, 45: 496-500.

Schmidt, G.D.; Hugghins, E.J. 1973. Acanthocephala of South American Fishes. Part I, Eoacanthocephala. Journal of Parasitology, 59: 829-835.

Thatcher, V.E. 1991. Amazon fish parasites. Amazoniana, 11:263-571.

RECEIVED: 20/07/2017

ACCEPTED: 05/10/2017

ASSOCIATE EDITOR: Claudia Keller 